\title{
TREE PLANTING AND FORESTRY PRACTICES IN THE PRAIRIE AREAS OF WESTERN CANADA
}

\author{
By C. A. EDWARDS \\ Indian Head, Saskatchewan
}

\section{The Importance of Natural Tree Growth}

In no other part of this Dominion are trees in natural growth more conspicuous by their absence than throughout the plains areas of the three Prairie Provinces. From the earliest years of land settlement to the present time, the need for establishing trees where none were found has been increasingly felt. It is generally recognized, and becoming more apparent every year, that tree growth is closely associated with soil fertility and other conditions, particularly climatic, influencing agriculture, on which largely depend the prosperity, comfort of living, and permanent development and progress of prairie communities.

\section{THE INFLUENCE OF TREES}

To clearly understand the tree planting situation of the past, present and future, the influences of tree growth under prairie conditions will be briefly reviewed at this point.

In the first place, trees provide the only practical means of protection from the ceaseless winds natural to the open prairie. On unprotected areas, soil erosion through wind action has reached alarming proportions in the last four decades. Nor is the open prairie the only area affected. Even in the naturally treed sections or park belt as it is known where land is being cleared for wheat growing, soil drifting is becoming a serious menace. Excessive clearing. of forest cover anywhere and particularly where light soil predominates, lowers the water table and quickly creates conditions for wind action to do its worst. Under such conditions the soil becomes impoverished and agricultural practices become very unprofitable.

\section{Systematic Planting and Strategic Value}

A carefully preserved forest cover where such naturally exists, supported by a systematic and strategic plan of planting trees on the open plains where wind erosion has made grain growing extremely hazardous, will add much in the future to bring about more stable and diversified farming practices. The use of trees in conjunction with present day recommendations as to soil management in crop production is considered sound policy. For example, trees planted in field shelter strips are additional guarantee against damage to crops by soil drifting.

\section{Agriculture AND Forestry INTERdependent}

Agriculture and our forest resources on which the farmers to the south depend for fuel, posts and building material, must be linked more closely and scientifically managed for the common good. The day is past when we may expect to attract more people to the land by the inducement of wheat production alone. The value of our soil is not in the growing of a single crop of wheat or oats but in its capacity to produce those crops profitably year after year. Farm tree planting for protection against wind action has 
been proved beyond doubt by thousands of farmers to be the only practical and profitable way of stabilizing production and maintaining permanent farm homes.

Purposes Served by Trees

Since farm tree planting was first sponsored by the Government it has been demonstrated that trees can be established on these prairies to serve the following purposes:

1. As windbreaks, shelterbelts and field shelters for farm home comfort and crop protection.

2. As screens around dams and dugouts to prevent silting and to maintain water volume.

3. As a means of preventing the movement and removal of top soil due to unrestricted wind action.

4. To conserve rainfall, retard evaporation of soil moisture, and prevent the loss of snow water in the spring due to rapid run off.

5. To reduce erosion on hill sides and rolling land and along the banks of coulees and ravines.

6. As plantations to supply the fuel and fence post requirements of the farm.

7. Farm shelterbelts make possible the growing of a variety of fruits and vegetables for home use.

These are a few of the more important values of tree growth which means so much to the economy of farm management.

\section{Scope of Farm Tree Planting}

Forty-odd years ago the idea of tree planting on the open prairie almost corresponded to wishful thinking, especially on the part of those who were occupying the land and building permanent farm homes. Their problem was to grow trees where trees apparently never grew before, and to keep them growing in a more or less wind-swept treeless country. This skepticism was overcome by the Federal Government tree planting policy, and the successful establishment of the Forest Nursery Stations at Indian Head and Sutherland, Saskatchewan.

On these Stations it was early demonstrated that by following certain practices trees of many kinds could be readily established and grown satisfactorily on practically any site in the open plains. As with other settlement problems there were failures in early tree planting attempts but these were for the most part due to lack of experience and knowledge of tree planting technique. Successes far outweighed failures and prairie tree planting has emerged as a sound economic practice of unquestionable value.

Present Extent of Farm Tree Planting

The Federal Government tree distribution policy has operated since 1901: The following is a classification of occupied farms in the three Prairie Provinces showing the extent of tree planting already attempted and the scope of future planting. 
PLANTING PRACTICES - EDWARDS

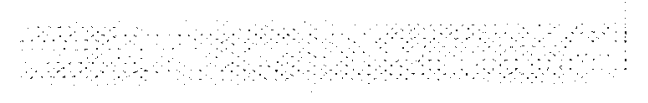

\begin{tabular}{|c|c|c|c|c|}
\hline \multirow[b]{2}{*}{ Item } & \multicolumn{4}{|c|}{ No. of Occupied Farms } \\
\hline & Manitoba & Saskatchewan & Alberta & Total \\
\hline Farm Census 1941 & 58,606 & 139,287 & 100,333 & 298,306 \\
\hline $\begin{array}{l}\text { Estimated naturally } \\
\text { wooded farms ... }\end{array}$ & 18,066 & 45,490 & 32,469 & 96,025 \\
\hline $\begin{array}{l}\text { Farms on which } \\
\text { shelterbelts have been } \\
\text { planted } 1901-1943 \ldots .\end{array}$ & 10,545 & 40,300 & 19,544 & 70,389 \\
\hline Treeless Farms …......... & 29,995 & 53,497 & 48,320 & 131,892 \\
\hline
\end{tabular}

Of the total occupied farms in the three provinces home shelterbelts have been planted on 6.5 per cent of the farms in Alberta, 13.5 per cent in Saskatchewan, and 3.6 per cent in Manitoba, or a combined total of 23.6 per cent. Allowing an estimated proportion of 32.2 per cent for naturally wooded areas there remains 44.2 per cent of occupied farms in the three provinces without trees as follows: Alberta 16.2 per cent, Saskatchewan 18 per cent, and Manitoba 10 per cent. Up to the present time some 195,000,000 broadleaf trees and 5,000,000 coniferous trees have been distributed and planted on prairie farms. The foregoing is approximately the past and present achievement in prairie tree planting on a general large scale policy.

Selection OF Tree Species

The successful establishment of tree growth depends chiefly on the selection of species for the purposes intended. The early growth of a tree is no sure indication of its suitability for the locality and planting site selected. A tree may be well suited for shade and in shelterbelt formation and have little merit from a wood producing standpoint. Wood production under prairie conditions is a long term process. Among the hardwoods Elm and Ash grow very slowly and nothing of fuel or fence post value may be expected from them in less than 20 to 25 years when planted in close shelterbelt arrangement. Poplar, Maple and Willow will yield returns in from 15 to 20 years, depending on the planting site and management. All hardwoods have a tendency to grow rather slowly from the 10th to 15 th years. With the softwoods such as Pine, Spruce, Tamarack, Siberian and European Larch, growth is relatively faster after the 8th to 10th year and quite uniform and sustained up to 40 to 50 years.

In the prairie region it is questionable if many farmers are interested in a straight woodlot planting proposition so long as the few cords they need each year are available in the regular market from natural resources. The generally accepted meaning of the term 'Woodlot' is a natural growth of trees managed and maintained by selective thinnings to supply fencing material, fuel and wood on the farm. On the prairies it is true we have natural bluffs of Poplar here and there but in these the best and most useful trees have been gradually cut out and natural regeneration takes place slowly.

It is unfortunate that in the past natural tree growth has been considered by many land operators a hindrance to the expansion of crop area and therefore regarded as an obstacle to be removed and destroyed. The result is that in practically every district there is an acute shortage of fuel and wood for local needs. 
It is recommended that native poplar bluffs should be more carefully preserved and managed for their future utility. These bluffs should be suitably fenced to prevent livestock from damaging the growing trees and retarding natural growth increase. Indiscriminate and uncontrolled cutting should be discouraged. Provision should also be made to protect bluffs from damage by carelessly started fires in the same manner as most farm home shelterbelts are isolated by plowed fireguards from 12 to 15 feet wide.

The farm shelterbelt is actually a dual purpose planting, primarily one of protection but capable of providing small fuel and fence posts from gradual thinnings later. Under prairie conditions we can expect only small tree growth with protection its main function and small fuel and fence post material a future return.

\section{GrowTH OF SPECIES}

The adaptability and growth of various tree species has been quite definitely established at the Dominion Forest Nursery Stations at Indian Head and Sutherland where extensive plantations of broadleaf and evergreen trees have been maintained for many years and the rate of growth recorded. Following are growth records by species on average prairie upland sites without irrigation. Manitoba Maple

Hardy. Fast growth. Excellent general purpose tree for shelterbelt and mixed woodlot on most soils. Good fuel and fence post wood. Growth 30 feet in 30 years with average diameter 4 to 5 inches.

Green Ash

Hardy. Grows best in heavy moist soil. Good tree in mixed shelterbelt preferably in outer rows. Sensitive to overshading. Wood tough, light, excellent fuel value. Excellent general purpose tree. Growth slow. 28 feet in 30 years. No wood returns of any value before 20 years. Average diameter 3 to 4 inches.

White Elm

Hardy. Moisture demanding. Very slow growing in mixed or pure stand. Wood hard and tough. Good fuel. Useful for small repairs, posts, fence pickets, etc. About 23 feet in 30 years and average diameter $21 / 2$ to $3 \frac{1}{2}$. inches.

Russian Poplar

Valuable as a quick fuel producer. Not long lived. Subject to stem and branch canker and trunk borer. Useful in shelterbelt mixture. May be grown in pure stand with careful management for fuel and fence posts. Growth 45 feet in 30 years. Diameter 6 to 8 inches.

Cottonwood

An excellent tree for moist heavy to medium soils. Rapid grower. Fair quality fuel. 42 feet in 30 years, average diameter 5 to 7 inches.

White Birch

Hardy. Rapid growth. Does well on all soils. Subject to borer under bark. No control and trees die rapidly when infestation occurs. Wood soft, perishable, good fuel. Good woodlot species. 30 feet. in 30 years, average diameter 4 to 5 inches. 


\section{While Spruce}

Very hardy. Thrives well on all soils. Growth rapid after first 5 or 6 years. Excellent for shelter and ornamental planting. Wood medium fuel value. 35 feet, in 35 years, average diameter 5 inches.

\section{Colorado Spruce}

Very hardy. Excellent windbreak, shelterbelt and ornamental tree. No serious insect pests. Grows rapidly first 6 to 8 years. Growth and diameter about same as White Spruce. 30 feet in 35 years, average diameter 5.2 inches.

Scotch Pine

Hardy. (several strains). Rapid grower. Not as good for windbreak as Spruce. Its branchy habit and tenacity of side branches are against it as a lumber tree here. Good fuel producer in 15 to 20 years. Average growth 34 feet in 35 years, average diameter 5 to 6 inches.

Jack Pine

Very hardy. Satisfactory for windbreak and woodlot. Good fuel and fence post value. Grows best on light to sandy soils. 28 feet in 35 years, average diameter $41 / 2$ inches.

Lodegpole Pine Hardy. Good windbreak and woodlot variety. Thin bark susceptible to sunscald. Valuable for fuel and posts. Grows well on sandy moist

: soils. Sensitive to alkali. 28 feet in 35 years, average diameter 4 inches. Tamarack

Hardy. Rapid growth. Excellent for woodlot. Wood useful. Has strength and durability. Fuel and fence post material in 25 to 30 years. Prefers moist soil. Average height 32 feet in 35 years, average diameter $41 / 2$ to 5 inches.

Siberian Larch

Very hardy. Excellent tree. Rapid uniform growth. Valuable wood for general purposes. Not selective of soil. Requires fair moisture. Growth more rapid than tamarack. Very straight tree. Side branches clear rapidly. Good poles. 42 feet in 35 years, average diameter 5.3 inches.

European Larch

Very hardy. Same characteristics as tamarack and Siberian larch büf lacks - straight growth. Very useful for general planting. Growth rate about the same as other larches. $31^{\prime} 6^{\prime \prime}$ in 35 years, average diameter 6 inches.

Other softwood species have been under test for many years in blocks of small woodlot proportion and following is the rate of growth.
Red Pine
$x$ White Pine
$x$ Bull Pine
Limber Pine
Norway Spruce
$31^{\prime} 6^{\prime \prime}$ in 30 years, average diameter 8.3
$26^{\prime} 4^{\prime \prime}$ in 30 years; average diameter 4.0
$23^{\prime} 1^{\prime \prime}$ in 30 years, average diameter 4.2
Black Hills Spruce
Balsam Fir
$x$ Douglas Fir
$24^{\prime} 0^{\prime \prime}$ in 30 years, average diameter 4.7
$32^{\prime} 9^{\prime \prime}$ in 35 years, average diameter 5.0
$35^{\prime} 4^{\prime \prime}$ in 35 years, average diameter 5.7
$36^{\prime} 6^{\prime \prime}$ in 35 years, average diameter 5.6

$x$ Not recommended for general planting under prairie conditions. 
It will be seen from these growth records that the growing of wood to a useful size under open prairie conditions is a very slow process. Everything considered it is doubtful if any prairie farmer who needs several cords of wood a year would be prepared to give the time and labor and acreage to a straight woodlot planting calculated to yield small returns in 20 to 30 years hence. The underlying idea of the planted farm woodlot is to utilize the sparer portions of the farm area which are not considered suitable for raising profitable agricultural crops and could well be devoted to tree growth.

Tree planting on open prairie is more or less a straight protection undertaking. Substantial prairie shelterbelts can be dual purpose plantings giving permanent protection to farm homes and fields from wind and storm, heat and cold, and yielding small fuel and fencing material proportionate to the size of the planting.

\section{Future Scope of Prairie Tree Planting}

Mention has been made of the influences and purposes served by trees which have to the present time been extensively planted on Western Farm Land. So far as the individual farmer is concerned, tree windbreaks and shelterbelts, the latter in substantial formation to serve the dual purposes of protection and wood production, will be his chief. interest and concern. There is scope here for a greatly expanded planting programme because of its importance to the economy of land utilization and permanent farm home life.

\section{Other Planting and Conservation Features}

There are other features of prairie tree planting and forest cover which might be termed collective projects inasmuch as they concern the common good and welfare of communities and districts as a whole. Such projects are:

1. Improvement and regeneration of natural tree growth.

2. Planting on municipal non-productive land areas, on sandy areas that have been abandoned.

3. Establishment of trees in groups, blocks and narrow belts on community pastures to serve as windbreaks and units of shade and shelter for stock on the range.

4. Reclamation of abandoned land.

These projects become essentially Government undertakings with the full cooperation of municipalities, Boards of Trade and other community organizations. It is only by the proper management and conservation of natural tree growth where such exists and the systematic planting of trees where they are needed most, that the resources of the country can be fully and advantageously utilized. There are many areas in this province and adjoining provinces where land by reason of steep slope, rocky nature and poor soil cannot be profitably used in general agriculture. The possibilities of tree planting on such areas invite serious consideration.

The future scope for tree planting and forestry practices in the western provinces is unlimited and the heritage we expect to hand down to the generations to come will be valuable only in proportion to the effort we make in our day. 